\title{
Komentarz do artykułu Kamila Zaworskiego, Roberta Latosiewicza, Piotra Majchera oraz Tomasza Derewieckiego pt. „Terapia manualna w diagnozowaniu i leczeniu zespołu mięśnia gruszkowatego - studium przypadku"
}

\author{
Gustaw Wójcik' ${ }^{1,2}$ \\ ${ }^{1}$ Zakład Balneoterapii, Katedra Rehabilitacji, Fizjoterapii i Balneoterapii Uniwersytetu Medycznego w Lublinie \\ ${ }^{2}$ Zakład Diagnostyki Obrazowej Szpitala Wojewódzkiego im. Zofii z Zamoyskich Tarnowskiej w Tarnobrzegu
}

Z nieukrywaną satysfakcją przeczytałem artykuł dotyczący diagnostyki i leczenia zespołu mięśnia gruszkowatego zamieszczony w MONZ 2015; 21(2): 215-220. Cieszy więc fakt podjęcia tej tematyki i przybliżenia czytelnikom obrazu wspomnianego schorzenia. Problem występowania zespołu mięśnia gruszkowatego (Piriformis Muscle Syndrome - PMS) wydaje się być marginalizowany ze względu na to, iż jest on przyczyną dolegliwości u stosunkowo niewielkiej populacji chorych cierpiących z powodu bólu dolnego odcinka kręgosłupa, miednicy oraz kończyn dolnych, a pewnie i dlatego, że przysparza sporo trudności diagnostyczno-terapeutycznych. Prawdopodobnie z powodu częstszego występowania dyskopatii i związanych z nią zespołów korzeniowych PMS $\mathrm{w}$ diagnostyce i leczeniu jest wielokrotnie pomijany. PMS jest odpowiedzialny za występowanie bólu okolicy lędźwiowej w $5-6 \%$ przypadków [1], choć niektórzy autorzy podają, że wielkość ta może sięgać nawet 17\% [2]. Biorąc pod uwagę rosnącą liczbę chorych uskarżających się na bóle dolnego odcinka kręgosłupa i miednicy, trzeba mieć na uwadze również inne jednostki ograniczające sprawność pacjentów.

PMS zaliczany jest do neuropatii nerwu kulszowego, której obraz kliniczny przypomina rwę kulszową lecz niedyskogenną, a wywołaną uciskiem nerwu kulszowego przez mięsień gruszkowaty.

Etiologia PMS zwykle zależy od osobniczych predyspozycji lub wad wrodzonych. Jednakże długotrwała, niewłaściwa pozycja podczas siedzenia również może powodować rozwój schorzenia, a głównym mechanizmem jest tutaj wewnętrzna rotacja biodra i ucisk nerwu kulszowego spowodowany skurczem mięśnia gruszkowatego.

Schorzenie występuje dość rzadko i na dodatek jest trudne do zdiagnozowania. Mało jest opracowań klinicznej oceny rozpoznania PMS oraz opracowań właściwej strategii leczenia [3].

W przypadku PMS nie ma czułej metody diagnostyki obrazowej. Radiogramy rentgenowskie, tomografia komputerowa, rezonans magnetyczny umożliwiają jedynie przeprowadzenie diagnostyki różnicowej z chorobą zwyrodnieniową krążka międzykręgowego czy zwężeniem lędźwiowego kanału kręgowego. Najmniej czułą metodą jest klasyczna rentgenodiagnostyka, bowiem poza tkanką kostną nie prezentuje wystarczająco dobrze tkanek miękkich takich jak mięśnie, a pomija zupełnie naczynia i nerwy. Natomiast dzięki tej metodzie można z powodzeniem ocenić na rzucie bocznym fizjologiczną krzywiznę (lordozę lędźwiową) oraz wysokość przestrzeni międzytrzonowych i objętość otworów międzykręgowych, a na rzucie przednio-tylnym (AP) ocenie można poddać występowanie skrzywień bocznych i rotację

Adres do korespondencji: dr n. med. Gustaw Wójcik, Zakład Diagnostyki Obrazowej, Wojewódzki Szpital im. Zofii z Zamoyskich Tarnowskiej w Tarnobrzegu, ul. Szpitalna 1

E-mail: gustaww@tlen.pl kręgów wzdłuż osi długiej kręgosłupa. Jeśli w obrazie RTG kręgosłupa w odcinku lędźwiowo-krzyżowym nie występują żadne odstępstwa od normy, można podejrzewać, że PMS jest przyczyną dolegliwości. Dużo doskonalszymi metodami są tutaj tomografia komputerowa i rezonans magnetyczny, gdyż umożliwiają ocenę krążka międzykręgowego i jego ewentualny konflikt $\mathrm{z}$ tkanką nerwową, przez co pośrednio wykluczają występowanie PMS. Poza tym metody te dają możliwość bezpośredniej oceny mięśnia gruszkowatego (jego długości i szerokości w stosunku do strony przeciwnej, bliznowacenia, ewentualnych ropni, krwiaków po urazach, a także zwłóknień po iniekcjach domięśniowych) - a to już znacznie przybliża do postawienia właściwej diagnozy i wdrożenia skutecznego leczenia [4].

W PMS z powodzeniem może być stosowane leczenie zachowawcze wraz z leczeniem farmakologicznym, polegającym na stosowaniu iniekcji z toksyny botulinowej. Jednak paradoksalnie samo stosowanie głębokich wstrzyknięć do mięśnia gruszkowatego może powodować włóknienie wokół nerwu kulszowego i nasilenie dolegliwości. Stąd też pojawiły się prace oceniające precyzję iniekcji wykonywanych pod kontrolą diagnostyki obrazowej $[5,6]$.

Generalnie, najbezpieczniejszą i najbardziej skuteczną metodą leczenia PMS pozostaje terapia manualna, jednak w przypadku gdy mamy do czynienia ze zmianami strukturalnymi, o skuteczności terapii decyduje leczenie chirurgiczne [7].

W zupełności zgadzam się z autorami artykułu, iż połączenie metod diagnostyki obrazowej oraz diagnostyki opartej na testach funkcjonalnych stanowi najwłaściwsze podejście umożliwiające postawienie szybkiego i precyzyjnego rozpoznania, a co za tym idzie przeprowadzenie skutecznego leczenia.

\section{PIŚMIENNICTWO}

1.Parlak A, Aytekin A, Develi S, Ekinci S. Piriformis syndrome: a case with non-discogenic sciatalgia. Turk Neurosurg. 2014; 24(1): 117-9.

2. Kean Chen C, Nizar AJ. Prevalence of piriformis syndrome in chronic low back pain patients. A clinical diagnosis with modified FAIR test. Pain Pract. 2013; 13(4): 276-81.

3. de la Peña Parra E, Calle Romero Y, García Sánchez VC, Sanz Pozo B. Low back pain of unfavourable progression. Semergen. 2013; 39(8): 453-5.

4. Arooj S, Azeemuddin M. Piriformis syndrome--a rare cause of extraspinal sciatica. J Pak Med Assoc. 2014; 64(8): 949-51.

5. Fabregat G, Roselló M, Asensio-Samper JM, Villaneuva-Pérez VL, Martínez-Sanjuan V, De Andrés J, Eichenberger U. Computer-tomographic verification of ultrasound-guided piriformis muscle injection: a feasibility study. Pain Physician. 2014; 17(6): 507-13.

6. Ozisik PA, Toru M, Denk CC, Taskiran OO, Gundogmus B. CT-guided piriformis muscle injection for the treatment of piriformis syndrome. Turk Neurosurg. 2014; 24(4): 471-7.

7. Erauso T, Pégorie A, Gaveau YM, Tardy D. Piriformis syndrome. Rev Prat. 2010; 60(7): 900-4. 